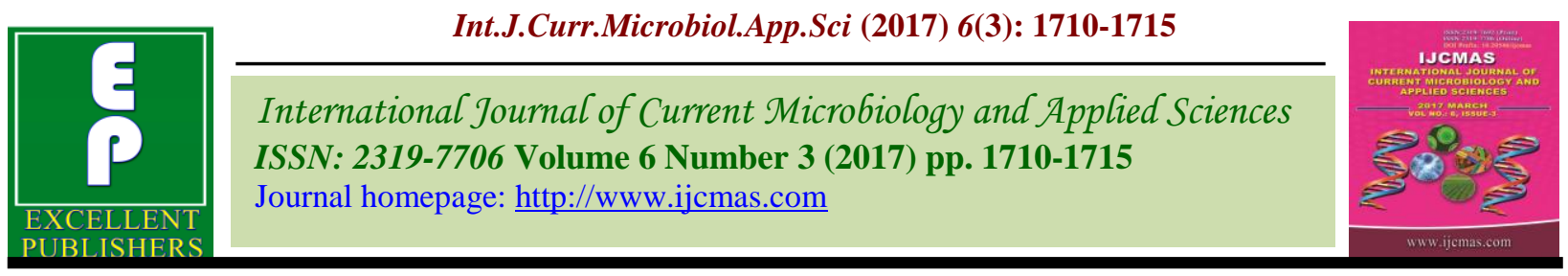

Original Research Article

https://doi.org/10.20546/ijcmas.2017.603.196

\title{
Influence of Seed Pelleting on Crop Performance and Seed Yield in French Bean (Phaseolus vulgaris L.) cv. Arka Anoop
}

\author{
K. Chaya Devi*, P. Balakrishna and J. Chandraprakash \\ Department of Seed Science and Technology, University of Agricultural Sciences, \\ GKVK, Bangalore - 65, India \\ *Corresponding author
}

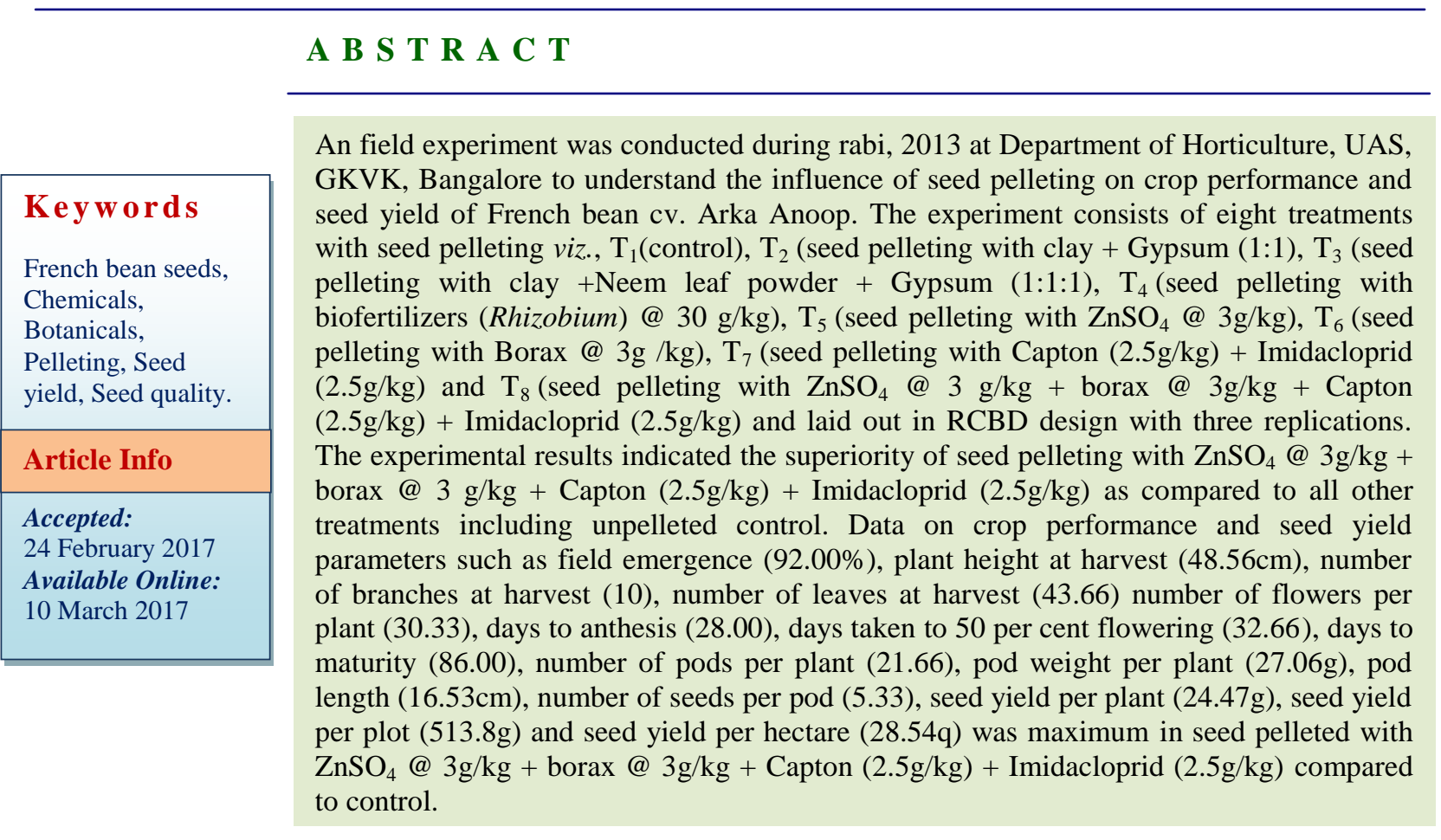

\section{Introduction}

French bean (Phaseolus vulgaris L.) is one of the most important vegetable pulse crop which is native to new world probably Central Mexico which belongs to family Fabaceae is a nutritious vegetable consumed as tender pods, shelled beans and dry beans. It has many synonyms like Snap bean, Kidney bean, Haricot bean and also called Rajmash in Hindi. It posses some medicinal properties which is useful in controlling diabetics and certain cardiac problems and it is a good natural cure for bladder burn. It has both carminative and reparative properties against constipation and diarrhoea (Duke, 1981).

Seed pelleting is the process of enclosing a seed with small quantity of inert material just large enough to produce globular unit of standard size to facilitate precision planting. The inherent material creates natural water 
holding media and provides small amount of nutrients to young seedlings. It also reduces the problem of thinning, gap filling and chemicals required in low quantity. Keeping in view the experiment is followed to know the outcome of the seed pelleting on crop performance and seed yield.

\section{Materials and Methods}

The experiment was conducted during rabi, 2013 at Department of Horticulture, University of Agricultural Sciences, GKVK, Bangalore. The experiment was laid out in randomized complete block design with eight treatments replicated thrice. The French bean seeds were pelleted with $\mathrm{T}_{1}$ (control), $\mathrm{T}_{2}$ (seed pelleting with clay + Gypsum $(1: 1), \mathrm{T}_{3}$ (seed pelleting with clay + Neem leaf powder + Gypsum (1:1:1), $\mathrm{T}_{4}$ (seed pelleting with biofertilizers (Rhizobium) @ 30g/kg), $\mathrm{T}_{5}$ (seed pelleting with $\mathrm{ZnSO}_{4} @ 3 \mathrm{~g} / \mathrm{kg}$ ), $\mathrm{T}_{6}$ (seed pelleting with Borax @ $3 \mathrm{~g} / \mathrm{kg}$ ), $\mathrm{T}_{7}$ (seed pelleting with Capton $(2.5 \mathrm{~g} / \mathrm{kg})+$ Imidacloprid $(2.5 \mathrm{~g} / \mathrm{kg})$ and $\mathrm{T}_{8}$ (seed pelleting with $\mathrm{ZnSO}_{4} @ 3 \mathrm{~g} / \mathrm{kg}+$ borax @ $3 \mathrm{~g} / \mathrm{kg}+$ Capton $(2.5 \mathrm{~g} / \mathrm{kg})+$ Imidacloprid $(2.5 \mathrm{~g} / \mathrm{kg})$. The spacing of $30 \times 10 \mathrm{~cm}$ was followed with net plot size of $1.2 \times 1.5 \mathrm{~m}$. All the recommended cultural practices for French bean crop were followed. Five normal plants were selected randomly in the net plot area and tagged with a label in each treatment to record the observations.

The observation on field emergence, plant height at harvest, number of branches at harvest, number of leaves at harvest, number of flowers per plant, days to anthesis, days taken to 50 per cent flowering, days to maturity, number of pods per plant, pod weight per plant, pod length, number of seeds per pod, seed yield per plant, seed yield per plot and seed yield per hectare was recorded. The data was statistically analysed and the results are presented in table 1 and 2 .

\section{Results and Discussion}

The results on crop performance and seed yield as influenced by the seed pelleting is significant and discussed here with the seeds pelleted with different chemicals and botanicals recorded significantly higher field emergence, plant height at harvest, number of branches at harvest, number of leaves at harvest, number of flowers per plant over control where as, days to anthesis, days taken to 50 per cent flowering, days to maturity was minimum in $\mathrm{T}_{8}$ over control. Among the different pelleting treatments, seeds pelleted with $\mathrm{T}_{8}$ (seed pelleting with $\mathrm{ZnSO}_{4} @ 3 \mathrm{~g} / \mathrm{kg}+$ borax @ 3g/kg + Capton $(2.5 \mathrm{~g} / \mathrm{kg})$ + Imidacloprid $(2.5 \mathrm{~g} / \mathrm{kg})$ recorded significantly highest field emergence $(92.00 \%)$, plant height at harvest $(48.56 \mathrm{~cm})$, number of branches at harvest (10.00), number of leaves at harvest (43.66) and number of flowers per plant (30.33) over all other treatments, while, control recorded lower values for these parameters.

The increased in growth parameter like field emergence, plant height, more number of branches, leaves and flowers per plant was found in seed pelleted with $\mathrm{ZnSO}_{4} @ 3 \mathrm{~g} / \mathrm{kg}+$ borax @ 3g/kg + Capton $(2.5 \mathrm{~g} / \mathrm{kg})+$ Imidacloprid $(2.5 \mathrm{~g} / \mathrm{kg})$ is due to enhanced carbohydrate metabolism and metabolic and physiological processes by plants (Ashour and Reda, 1972) and increased cell division. Similar increased plant height and number of leaves noticed with $\mathrm{ZnSO}_{4}$ may be ascribed to its involvement in biosynthesis of auxin (Krishnasamy, 2003) and cell expansion. Masuthi (2005) in cowpea and Supreeta Angadi (2004) in soybean. While, Capton and Imidacloprid might have provided protection against seed and soil borne pathogens and insects leading to early vigorous growth of plants, that leads to early reproduction phase. (Manjunath, 2009). 
Table.1 Influence of seed pelleting on crop performance in French bean cv. Arka Anoop (Phaseolus vulgaris)

\begin{tabular}{|c|c|c|c|c|c|c|c|c|}
\hline Treatments & $\begin{array}{c}\text { Field } \\
\text { emergence } \\
\text { at } 20 \text { DAS } \\
(\%)\end{array}$ & $\begin{array}{c}\text { Plant } \\
\text { height at } \\
\text { Harvest } \\
(\mathrm{cm})\end{array}$ & $\begin{array}{c}\text { Number of } \\
\text { branches } \\
\text { per plant } \\
\text { at Harvest }\end{array}$ & $\begin{array}{c}\text { Number } \\
\text { of leaves } \\
\text { at } \\
\text { Harvest }\end{array}$ & $\begin{array}{l}\text { Days to } \\
\text { anthesis }\end{array}$ & $\begin{array}{c}\begin{array}{c}\text { Number } \\
\text { of } \\
\text { flowers } \\
\text { per plant }\end{array} \\
\end{array}$ & $\begin{array}{c}\text { Days taken } \\
\text { to } 50 \text { per } \\
\text { cent } \\
\text { flowering } \\
\end{array}$ & $\begin{array}{l}\text { Days to } \\
\text { maturity }\end{array}$ \\
\hline $\mathbf{T}_{1}$ & 74.66 & 35.20 & 7.33 & 37.33 & 34.66 & 19.33 & 38.66 & 92.66 \\
\hline $\mathbf{T}_{2}$ & 77.00 & 37.43 & 8.00 & 38.33 & 33.66 & 20.33 & 38.33 & 91.66 \\
\hline $\mathbf{T}_{\mathbf{3}}$ & 79.33 & 39.60 & 8.33 & 39.33 & 32.33 & 21.66 & 37.00 & 90.66 \\
\hline $\mathbf{T}_{4}$ & 81.00 & 41.63 & 8.66 & 40.33 & 31.33 & 23.33 & 36.33 & 89.66 \\
\hline $\mathbf{T}_{5}$ & 86.33 & 44.73 & 9.00 & 42.33 & 29.33 & 27.66 & 34.33 & 87.33 \\
\hline $\mathbf{T}_{6}$ & 83.67 & 43.23 & 8.66 & 41.33 & 30.33 & 26.00 & 35.33 & 88.33 \\
\hline $\mathbf{T}_{7}$ & 89.00 & 46.36 & 9.66 & 43.33 & 28.33 & 29.33 & 33.33 & 86.66 \\
\hline $\mathbf{T}_{8}$ & 92.00 & 48.56 & 10.00 & 43.66 & 28.00 & 30.33 & 32.66 & 86.00 \\
\hline Grand mean & 82.87 & 42.09 & 8.70 & 40.75 & 31.00 & 24.75 & 35.75 & 89.12 \\
\hline S. Em \pm & 0.32 & 0.25 & 0.21 & 0.33 & 0.26 & 0.25 & 0.26 & 0.29 \\
\hline C.D $(P=0.05)$ & 0.98 & 0.76 & 0.66 & 1.00 & 0.79 & 0.76 & 0.79 & 0.89 \\
\hline $\mathrm{CV}(\% \mathrm{~s})$ & 4.90 & 10.20 & 4.34 & 5.40 & 4.47 & 5.76 & 6.27 & 6.57 \\
\hline
\end{tabular}


Table.2 Influence of seed pelleting on seed yield in French bean (Phaseolus vulgaris) cv. Arka Anoop (Phaseolus vulgaris)

\begin{tabular}{|c|c|c|c|c|c|c|c|}
\hline Treatments & $\begin{array}{l}\text { Number of } \\
\text { pods per } \\
\text { plant }\end{array}$ & $\begin{array}{c}\text { Pod } \\
\text { weight } \\
\text { per } \\
\text { plant (g) }\end{array}$ & $\begin{array}{c}\text { Pod } \\
\text { length } \\
(\mathbf{c m})\end{array}$ & $\begin{array}{l}\text { Number } \\
\text { of seeds } \\
\text { per pod }\end{array}$ & $\begin{array}{l}\text { Seed yield } \\
\text { per plant } \\
\text { (g) }\end{array}$ & $\begin{array}{l}\text { Seed yield } \\
\text { per plot (g) }\end{array}$ & $\begin{array}{l}\text { Seed yield per } \\
\text { hectare }(\mathbf{q})\end{array}$ \\
\hline $\mathbf{T}_{1}$ & 15.66 & 19.32 & 12.80 & 3.33 & 17.42 & 366.0 & 20.32 \\
\hline $\mathbf{T}_{2}$ & 16.66 & 19.84 & 13.23 & 3.66 & 18.12 & 380.5 & 21.14 \\
\hline $\mathbf{T}_{3}$ & 17.66 & 22.22 & 13.63 & 4.00 & 19.13 & 401.7 & 22.31 \\
\hline $\mathbf{T}_{4}$ & 18.33 & 23.74 & 14.06 & 4.00 & 20.25 & 405.5 & 22.50 \\
\hline $\mathbf{T}_{5}$ & 20.33 & 24.73 & 14.90 & 5.00 & 22.15 & 465.1 & 25.84 \\
\hline $\mathbf{T}_{6}$ & 19.33 & 23.74 & 14.46 & 4.33 & 21.43 & 450.2 & 25.01 \\
\hline $\mathbf{T}_{7}$ & 21.00 & 25.66 & 15.56 & 5.00 & 22.95 & 481.1 & 26.72 \\
\hline $\mathbf{T}_{8}$ & 21.66 & 27.06 & 16.53 & 5.33 & 24.47 & 513.8 & 28.54 \\
\hline Grand mean & 18.83 & 23.29 & 14.40 & 4.33 & 20.74 & 433.0 & 24.04 \\
\hline S. Em \pm & 0.27 & 0.21 & 0.08 & 0.19 & 0.13 & 2.69 & 0.13 \\
\hline C.D $(P=0.05)$ & 0.82 & 0.63 & 0.26 & 0.58 & 0.41 & 8.61 & 0.41 \\
\hline CV (\%) & 4.49 & 6.56 & 5.04 & 7.76 & 9.15 & 10.98 & 11.28 \\
\hline
\end{tabular}


While, days to anthesis (28.00), days taken to 50 per cent flowering (32.66) and days to maturity (86.00) were early in seeds pelleted with $\mathrm{ZnSO}_{4} @ 3 \mathrm{~g} / \mathrm{kg}+$ borax @ 3g/kg + Capton $(2.5 \mathrm{~g} / \mathrm{kg})+$ Imidacloprid $(2.5 \mathrm{~g} / \mathrm{kg})$ compared to control. The earliness in flowering behaviour may be ascribed to better growth of plants as reflected with higher number of leaves resulting in higher photosynthetic activity triggering in synthesis of hormones involved in flower behaviour and their active role in various physiological and bio-chemical processes of the plants. Similar results were also reported by Masuthi (2005) in cowpea and Balaji (1990) and Supreeta Angadi (2004) in soybean.

Among pelleting treatments $\mathrm{ZnSO}_{4}$ @ $3 \mathrm{~g} / \mathrm{kg}$ + borax @3g/kg + Capton $(2.5 \mathrm{~g} / \mathrm{kg})+$ Imidacloprid $(2.5 \mathrm{~g} / \mathrm{kg})$ recorded highest number of pods per plant (21.66), pod weight per plant $(27.06 \mathrm{~g})$, pod length $(16.53 \mathrm{~cm})$, number of seeds per pod (5.33), seed yield per plant $(24.47 \mathrm{~g})$, seed yield per plot $(513.8 \mathrm{~g})$ and seed yield per hectare (28.54q) respectively over control which was due to the involvement in sugar synthesis and its efficient translocation for seed formation and development (Berger, 1949; Shkolnik and Abdurashitov,1958). Similar results with boron were reported by Srimathi et al. (2001) and Supreeta Angadi (2004) in soybean and Masuthi (2005) in cowpea and Angumuthu (1991) in miner millets. Zinc element is involved in auxin metabolism, plays a pivotal role in seed size and development. The second phase of seed development requires adequate amount of zinc dependent upon auxin for seed development. Hence the study can be concluded seed pelleted with (T8) ZnSO4@30 g/kg + borax @ 30 g/kg + Capton $(2.5 \mathrm{~g})+$ Imidacloprid $(2.5 \mathrm{~g} / \mathrm{kg})$ could be recommended for the French bean cultivation to harvest higher seed yield and seed quality.

\section{References}

Angumuthu, R., 1991, Studies on seed pelleting, physiological maturity, sowing quality and storage of small millets. M.Sc. (Agri.) Thesis, Tamilnadu Agric. Univ., Coimbatore.

Ashour, N.I. and Reda, F., 1972, Effect of foliar application of some microelements on growth and some physiochemical properties of sugarbeet growth in winter season. Curr. Sci., 41 (4) :146-147.

Balaji, D. S., 1990, Studies on the seed soil relationship in certain crops paddy, greengram, soybean, redgram, sunflower, groundnut and cotton. $M$. Sc. (Agri.) Thesis, Tamil Nadu Agric. Univ., Coimbatore, India.

Berger, K.C., 1949, Boron in soils and crops. Adv. in Agron., 1 : 321-351.

Duke, J. A., 1981, Handbook of legumes of world economic importance. New York, USA/ London, UK : pp, 195200.

Krishnasamy, V., 2003, Seed pelleting principles and practices. ICAR Short Course on Seed Hardening and Pelleting Technologies for Rainfed/Garden Land Ecosystems : May 27 to June 5, Tamil nadu Agric. Univ., Coimbatore, pp. 96.

Masuthi, D. A., 2005, Effect of phosphorous, zinc and boron on fruit set, seed yield and quality of vegetable cowpea (Vigna anguiculata (L.). M.Sc. (Agri) Thesis, Univ. Agric. Sci., Dharwad, Karnataka (India).

Manjunath, S. N., Deshpande, V. K., Sridevi, O, Uppar, D, S., Babalad. H. B. and RAO. M. S. L., 2009, Influence of seed pelleting on crop growth, seed yield and quality of paprika chilli (Capsicum annuum L.). Karnataka J. Agric. Sci., 22 (4) : (762-764).

Shkolnik and Abdurashitov, S.A., 1958, 
Influence of micro-elements on synthesis and translocation of carbohydrates. Pl. Phy., USSR, 5 (5) : 393-399.

Srimathi, P., Sastri, G. and Malarkodi, K., 2001, Influence of seed pelleting on crop establish of soybean. Nat.Symp.
Coimbatore, pp. 107.

Supreetha Angadi, 2004, Effect of seed pelleting on field performance and storability in soybean (Glycine max (L.) Merrill). M.Sc. (Agri) Thesis, Univ. of Agric. Sci., Dharwad, Karnataka, India.

\section{How to cite this article:}

Chaya Devi, K., P. Balakrishna and Chandraprakash, J. 2017. Influence of Seed Pelleting on Crop Performance and Seed Yield in French Bean (Phaseolus vulgaris L.) cv. Arka Anoop. Int.J.Curr.Microbiol.App.Sci. 6(3): 1710-1715. doi: https://doi.org/10.20546/ijcmas.2017.603.196 